\title{
Developing an Ergonomic and Flexible Gawangan Batik Design
}

\author{
Irma Russanti, Yulistiana, Priyo Heru Adi Wibowo \\ Home Economic Department \\ Uiversitas Negeri Surabaya \\ Surabaya, Indonesia \\ irmarussanti@unesa.ac.id
}

\begin{abstract}
Gawangan is a tool used to put cloth when batik process. Problems faced by craftsmen are often designs made less ergonomic gawangan less comfortable when used. The method used is the development of product design from existing gawangan design. The result is the realization of ergonomic and flexible gawangan batik, which can be arranged high low, tailored to the needs of the craftsmen when doing batik process. In addition, the development of gawangan design has other functions.
\end{abstract}

Keywords—gawangan batik, design development, ergonomics, flexible

\section{INTRODUCTION}

The production process of batik tulis (handmade/ traditional/ manual-made batik) from materials into a ready to be marketed batik is through several stages such as: preparing materials, cooking cloth, drying, designing/tracing motifs, applying wax (waxing process), process of nembok (constructing walls), dye / dyeing for the base of the fabric, the process of wax pelorodan (eliminating the wax), and drying.

Due to the development of batik business and increasing demand, there are obstacles to meet the needs of the market especially in the production, the process of applying wax and the nembok in particular. To date, the process of applying wax and nembok are still manually done or by using conventional gawangan. Of the whole process of batik production, $60 \%$ of time and energy are just for the process of applying wax and nembok. This is what underlies an innovation in order to gain more efficient time and energy as well as opportunities to meet market needs. Then, it is expected that the production and welfare of micro entrepreneurs increase.

From the analysis of the above problems, it is necessary to develop ergonomic and flexible design so that the craftsmen are more comfortable and not easily exhausted. This is because the position is in accordance with the posture of each craftsman and assists the development of management in order to increase production, quality and sales and marketing of the batik.

\section{METHOD}

Based on the purpose of this research, the type of research used is developmental research which aims to produce a particular product, test the effectiveness and refine the product. In general, developmental research is to produce, develop a new product or refine an existing product, which can be accounted for. Products can be prototypes and designs [1]. The product to be developed is batik used by industry to make batik more ergonomic. Processes and results of gawangan are described to know the effectiveness of the product development. This research will simplify the process during batik making and is more effective. The process of applying wax becomes easier by eliminating one step which leads to a decrease in the cost of making batik [2]

The research procedure consists of several stages. The first stage is doing field observation to analyze the actual problem faced by batik craftsmen. The second one is determining urgent issues that must be addressed to improve the productivity of micro business. The third stage is providing a solution of the problem (i.e. the problem of batik production process) by making ergonomic and flexible gawangan. The fourth stage is transferring the technology by making the ergonomic and flexible gawangan and seats after the discussion with batik craftsmen. The last stage is conducting trials level of security, comfort and flexibility of the gawangan.

\section{RESULTS AND DISCUSSION}

\section{A. Preparation of Making Gawangan}

This begins by conducting a survey of places selling gawangan materials, namely the various types and sizes of stainless steel pipes, in order to obtain the suitable type and size of stainless steel pipe (see Fig. 1).
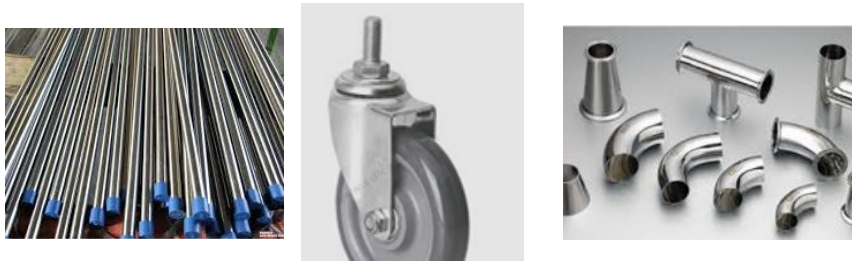

Fig. 1. Materials for making gawangan.

\section{B. Process of Making Gawangan}

The process of making gawangan begins with measurement, cutting, grinding, welding, and assembly. The steps are done carefully to avoid mistakes. The performed steps are shown in the following Fig. 2. 

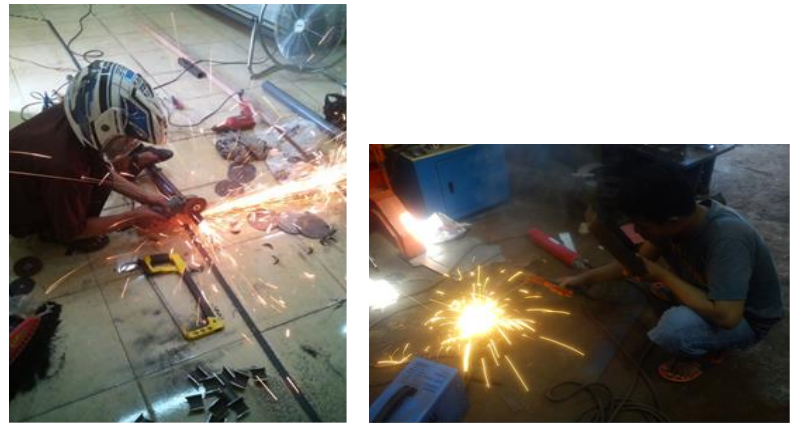

Fig. 2. Process of making gawangan.

At this stage, stainless steel pipes are ready to be assembled sequentially and systematically, in order to form a series of gawangan in accordance with the plan, as shown in the following Fig. 3 and Fig. 4.

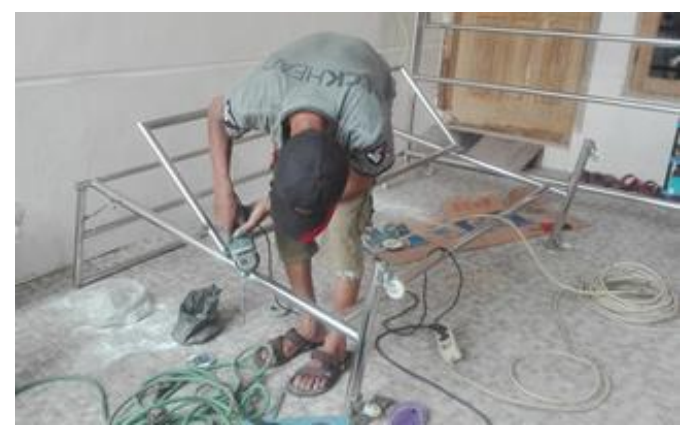

Fig. 3. Gawangan making process.

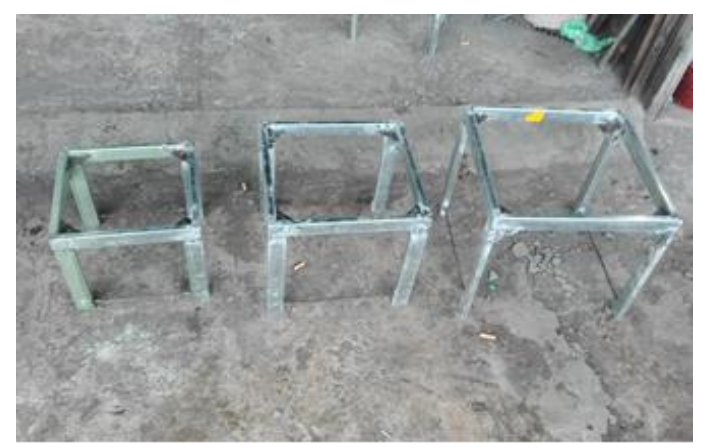

Fig. 4. Seats making process.

To complete the gawangan, 3 (three) seats are made in 3 different sizes. Frame seats are made of square hollow stainless steel, so it can stand solid and balanced when later used to sit, as shown in the picture. After going through several stages in the process of making, gawangan and its three seats are done in accordance with the plan, as shown in Fig. 5

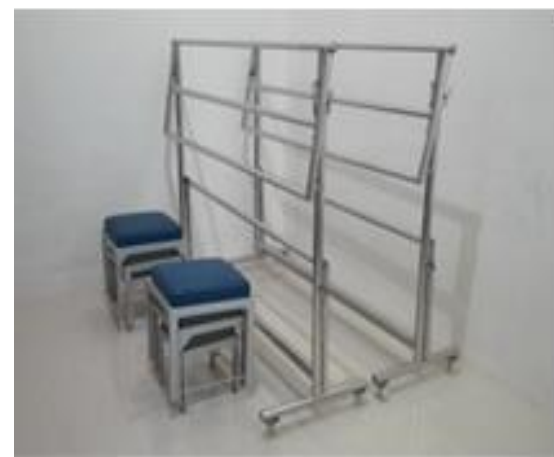

Fig. 5. A set of gawangan and the seats.

Gawangan with a rectangular structure can be adjusted its height as needed and is equipped with a clamp. The top of the gawangan can be set its direction, forward or back from the user side, as needed.

\section{Trials Process}

Trials are to determine whether the designed gawangan is ergonomics and flexible in terms of comfort and safety. Hopefully if the gawangan users feel the comfort and safety when using the gawangan, the productivity in the stage of applying wax and nembok will increase. Trials conducted by batik craftsmen are as the following Fig. 6.and Fig. 7.
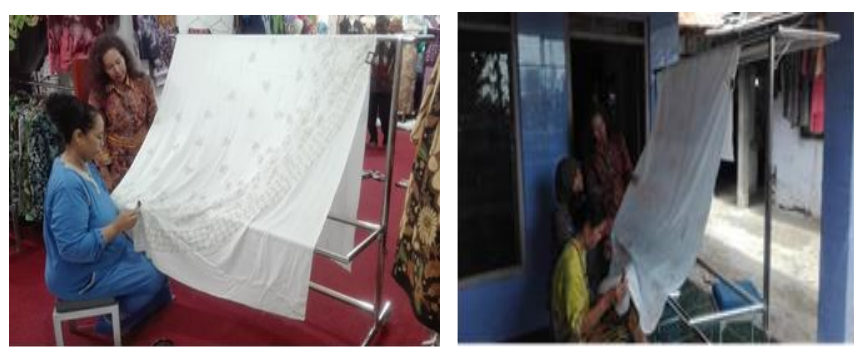

Fig. 6. Using gawangan to support the batik making.
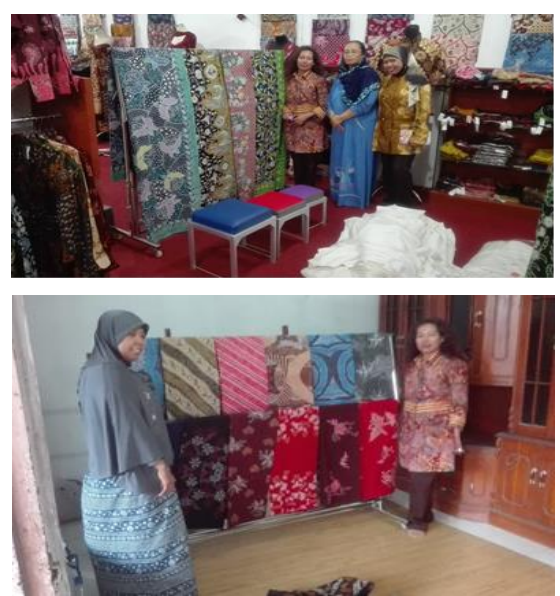

Fig. 7. Using gawangan as batik display. 
Relating to the multi functions of gawangan, the results of the test stated that the gawangan also can be used as a display tool to display batik cloth so it will look more beautiful.

\section{CONCLUSION AND SUGGESTION}

Based on the activities done through stages; analyzing the situation, studying the problems faced by Partners in the production stage of batik, giving solutions and target that is to result gawangan designed by the team, several points are concluded that, first, gawangan is ergonomics, flexible and easy to use. This makes the craftsmen feel comfortable in the process of batik, especially when applying wax and constructing the walls. Second, gawangan that is not used can be stored in practical because it does not require a large place. Third, seats are with multilevel size, ergonomic and flexible, so that they can be used by craftsmen according to the proportion of their body.

\section{ACKNOWLEDGMENT}

Deeply indebted for UMK Batik Patrangmas and Sarikenungu at Sidoarjo, and also the goverment involved and help run this research.

\section{REFERENCES}

[1] Harsono and Okumura, Teknologi Pengelasan Logam (Pradnya Paramita, 1981).

[2] Kharid, Design and Development of Semi Automatic Canting Tool (Electrical), (Faculty of Manufacturing Engineering, University Malaysia Pahang, 2012).

[3] Aliya, Batik Pekalongan, (Rama Edukasitama, Jakarta, 2010).

[4] Tata and Saito, Pengetahuan Bahan Teknik, (Pradnya Paramita, Jakarta, 1985).

[5] Kusrianto, Batik - Filosofi, Motif, dan Kegunaan, (Andi Offset, Yogyakarta, 2013).

[6] Hindayani, Mengenal dan Membuat Batik, (Buana Cipta Pustaka, Jakarta, 2009).

[7] Hertanto, Unesco Akui Batik Milik Indonesia, (2009) retrieved from www.detikNews.com.

[8] Nieman G, Elemen Mesin Jilid 1, (Erlangga, Jakarta, 1999).

[9] Direktorat Riset dan Pengabdian Masyarakat, Kemenristek dan Pendidikan Tinggi, Panduan Pelaksanaan Penelitian dan Pengabdian Kepada Masyarakat di Perguruan Tinggi Edisi X, (Kemeristekdikti, Jakarta, 2016). 